\title{
5 \\ Disputation, Kinship and Land Tenure in Western Arnhem Land
}

\author{
Mark Harvey
}

\section{Introduction}

This chapter considers the effects of varying levels of disputation on terminologies within the domains of kinship and land tenure. It compares reconstructions of disputation in precolonial Australia with materials on patterns of disputation over the postcolonial period. Precolonially, reconstructions agree that kinship terminologies across Australia were used to frame marriage claims, and involved a high level of disputation (Keen 1982; Merlan 1988). Given the prominence of kinship terminologies in marriage disputes, inconsistencies between and indeterminacies within terminologies were highlighted over time and more likely to be addressed. In contrast, reconstructions agree that land tenure was rarely presented as an overt cause of disputation (Stanner 1979, p. 233; Sutton 1978, pp. 77-8). Therefore, inconsistencies and indeterminacies were less foregrounded and subsequently less likely to be addressed.

Bourdieu (1977, pp. 159-71) drew a distinction, opposing the universe of the discussed, orthodoxy and heterodoxy (opinion), to the universe of the undiscussed - the doxa: 
It is by reference to the universe of opinion that the complementary class is defined, the class of that which is taken for granted, doxa ... The critique which brings the undiscussed into discussion, the unformulated into formulation, has as the condition of its possibility objective crisis, which, in breaking the immediate fit between the subjective structures and the objective structures ... Crisis is a necessary condition for a questioning of doxa but is not in itself a sufficient condition for the production of critical discourse. (pp. 168-9)

In quantitative terms, the opposition is probably better analysed as a continuum from most discussed to least discussed. Precolonially, kinship veered towards the 'discussed' pole of the continuum, as formulation and presentation of opinions on kinship terminologies were a frequent social practice. By contrast, land tenure leaned towards the doxa pole of the continuum, with the formulation and presentation of opinions on land tenure terminologies being an infrequent social practice. I suggest that colonisation constituted an objective crisis that led to changes in the frequency in which opinions on kinship and land tenure were required. This exposed gaps in people's capacities to offer opinions on subjects such as land tenure, and reduced opportunities for the offering of opinions on other subjects such as kinship. As opinions proffered by knowledgeable people are central to analyses of sociality, it is important to consider the factors that affect the offering of opinions. Given that both the precolonial and postcolonial trajectories of kinship and land tenure differ significantly, a comparison of the two will assist in highlighting these relevant factors.

Western Arnhem Land has multiple terminologies in the domains of kinship and land tenure. In addition to egocentric kin terminologies, there are three sociocentric kin terminologies: matry, matrimoiety and subsection. These sociocentric terminologies are further discussed under the section 'Kin Terminologies' in this chapter. There are three terminologies that relate to land tenure: language names, gunmogurrgurr names and yigurrumu exclamations (Berndt \& Berndt 1970), which are further discussed under the section 'Land Tenure Terminologies'. Therefore, there is a substantial evidentiary base for examining people's capacities to offer opinions that explain indeterminacies within terminologies, and relationships between terminologies in western Arnhem Land. The data in this chapter are primarily from the northern Kakadu - Gunbalanya area, but some data from adjacent areas are also considered. 


\section{Reconstruction in the Northern Kakadu - Gunbalanya Area}

In any exercise in reconstruction, it is important to set out the parameters of the database on which the reconstruction is based. As previously mentioned, colonisation is a central parameter in Australia—as in much of the world - and it has had a drastic impact on the northern Kakadu Gunbalanya area. Figure 15 presents a reconstruction of the associations of the technically distinct languages in the area at the time of colonisation. (For a more detailed analysis of land and language relationships in the northern Kakadu - Gunbalanya area, see Harvey 2002b).

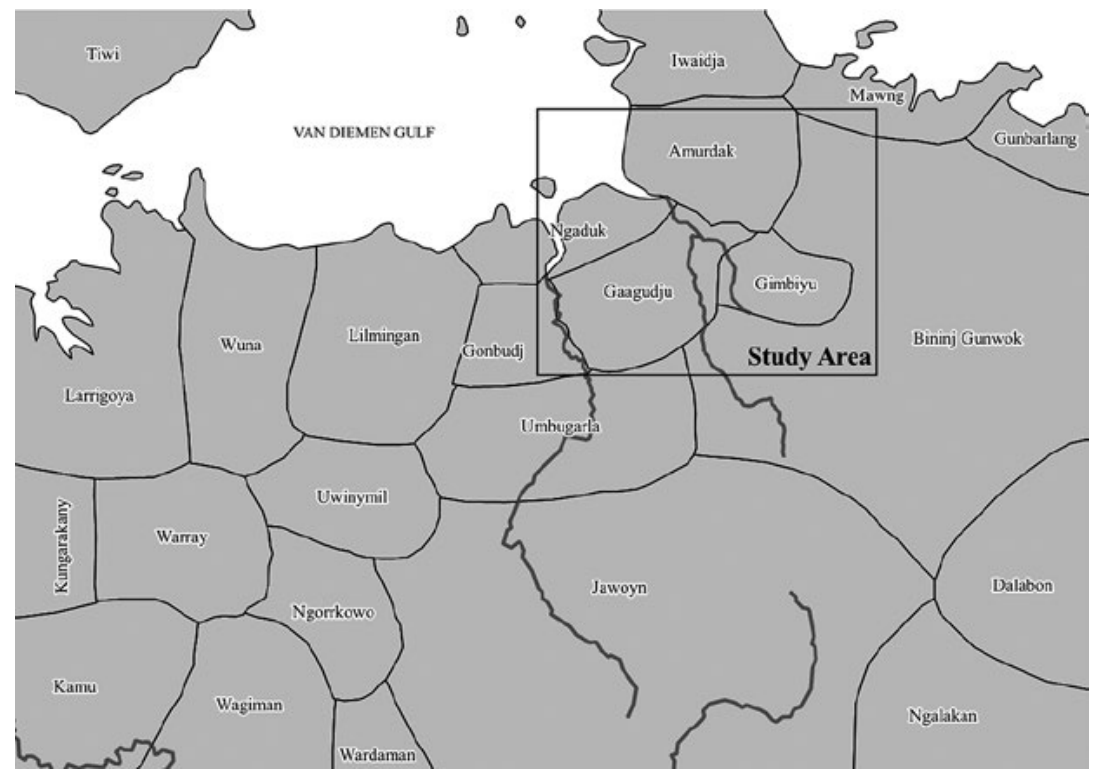

Figure 15: Northern Kakadu - Gunbalanya-languages at time of colonisation.

Source: Author's work.

The most important effect of colonisation was a drastic population collapse. By the 1970s, the Aboriginal population with precolonial connections to the northern Kakadu - Gunbalanya area was approximately 4 per cent of the population that could be reconstructed as having connections to the area at colonisation, with the bulk of the collapse occurring in the period from 1880 to 1920 (Keen 1980, pp. 37-44). 
This population collapse had many effects including an extreme reduction in the range of languages acquired by children. Of the languages in the 'study area' shown in Figure 15, only Bininj Gunwok has been acquired as a first language since around 1940. From approximately 1920, it appears that other languages were most frequently used among people who were principally residents further to the west, on the buffalo country (Harvey 2002b, p. 27).

The data presented in this chapter have two principal sources. The first is the extensive research of Berndt and Berndt (1970, p. xiv) at Gunbalanya, which commenced in 1947. The second is the research undertaken in the period from 1970 to 1990 that was associated with the establishment of the Kakadu National Park and related land claims (Keen 1980), and which also includes my own research. Consequently, the great bulk of data were provided by people who were using Bininj Gunwok as their principal daily language; however, there is also some data from people who were using Kriol as their principal daily language. Data from languages other than Bininj Gunwok were provided by people who had not been actively using those languages for some considerable time. Among the other languages, the most extensive data are on Gaagudju. There are limited materials on Amurdak, Giimbiyu and Umbugarla, and there is nothing on Bugurnidja, Gonbudj or Ngombur.

Given this information, the database suggests a greater uniformity in kinship and land tenure practices than was the precolonial situation. The discussion in this chapter is primarily from a Bininj Gunwok perspective, with data from other languages provided where possible.

\section{Kin Terminologies}

Only for Bininj Gunwok and Gaagudju are sufficient data available to describe egocentric terminologies. Among Bininj Gunwok speakers, egocentric terminologies vary considerably in their basic structure. In the northern Kakadu - Gunbalanya area, the basic structure is an unusual asymmetric system, with first preference marriage of a man to his actual FZDDD (Harvey 2001, p. 121). The Gaagudju terminology shows the same structure. In addition to the basic terminology used in everyday life, Bininj Gunwok has many other terminologies used in more restricted circumstances. 
In addition to egocentric terminologies, three types of sociocentric terminologies are found in this area: matries, matrimoieties and subsections. The patrimoiety terms duwa and yirritja have also been recorded in the area since the 1940s; however, these terms are clearly postcolonial borrowings from eastern Arnhem Land (Berndt \& Berndt 1970, p. 57).

Among the sociocentric terminologies, the matries have the widest geographical range. The principal terms used in the languages of the area are set out in Table 7.

Table 7: Matry terminologies.

\begin{tabular}{|c|c|c|c|c|c|}
\hline Matry & Gaagudju Fem & Gaagudju Masc & Iwaidja & Amurdak & $\begin{array}{l}\text { Bininj } \\
\text { Gunwok }\end{array}$ \\
\hline 1 & $\begin{array}{l}\text { njing-garra- } \\
\text { ngaalbu }\end{array}$ & $\varnothing$-yarra-ngaalbu & $\begin{array}{l}\text { man-jarri- } \\
\text { wuli }\end{array}$ & $\begin{array}{l}\text { warri- } \\
\text { yarnkurrk }\end{array}$ & $\begin{array}{l}\text { yarri- } \\
\text { yarnkurrk }\end{array}$ \\
\hline 2 & $\begin{array}{l}\text { njing-garra- } \\
\text { barnaadjinggi } \\
\text { njing-garra- } \\
\text { barnaadju } \\
\end{array}$ & $\begin{array}{l}\varnothing \text {-yarra- } \\
\text { barnaadjinggi } \\
\varnothing \text {-yarra-barnaadju }\end{array}$ & $\begin{array}{l}\text { man-jarr- } \\
\text { wurrkarr }\end{array}$ & warr-ukarr & $\begin{array}{l}\text { yarri- } \\
\text { wurrkarr }\end{array}$ \\
\hline 3 & njing-garr-mangiiru & $\varnothing$-yarr-mangiiru & $\begin{array}{l}\text { man-jarri- } \\
\text { wujali }\end{array}$ & warri-wujali & yarri-burrik \\
\hline 4 & njing-garraa-djawa & $\varnothing$-yarraa-djawa & $\begin{array}{l}\text { man- } \\
\text { barlkidj }\end{array}$ & $\begin{array}{l}\text { warri- } \\
\text { yarniny }\end{array}$ & $\begin{array}{l}\text { yarri- } \\
\text { yarninj }\end{array}$ \\
\hline 5 & djimburruwoodjbu & djimburruwoodjbu & $\begin{array}{l}\text { man-jarri- } \\
\text { marrangaj }\end{array}$ & $\begin{array}{l}\text { warri- } \\
\text { marrangaj }\end{array}$ & \\
\hline
\end{tabular}

Source: Author's work.

The matry terminologies are discussed in detail in Harvey and Garde (2015). For current purposes, it should be noted that all the terminologies involve significant linguistic irregularities synchronically, which provides evidence that the matry system is not of recent origin in western Arnhem Land. Only the first four matries were historically found throughout the region. The linguistic evidence suggests that Matry 5 was principally associated with Amurdak and Iwaidja (Harvey \& Garde 2015, p. 260). The Gaagudju term djimburruwoodjbu means 'white cockatoo', which is one of the principal totems of Matry 5. There is no Bininj Gunwok term for Matry 5 (Berndt \& Berndt 1970, p. 65).

The matrimoiety terms in western Arnhem Land are mardku and $n$ garradjku. These terms form part of the Bininj Gunwok and Iwaidja lexicons, but did not form part of the Gaagudju lexicon. There is some uncertainty as to whether they formed part of the Amurdak lexicon (Harvey \& Garde 2015, p. 238). 
Subsection terminologies formed part of the Bininj Gunwok and Iwaidja lexicons. They did not form part of the lexicons of Gaagudju and Umbugarla, which were the languages to the west of Bininj Gunwok. As with the matrimoiety terms, there is some uncertainty as to whether they formed part of the Amurdak lexicon (Harvey \& Garde 2015, p. 238). The Gunbalanya Bininj Gunwok terminology, following first preference marriage, is set out in Table 8 .

Table 8: Gunbalanya Bininj Gunwok subsection terminology.

\begin{tabular}{|c|l|c|l|c|}
\hline \multicolumn{2}{|l|}{ ngarradjku matrimoiety } & & \multicolumn{2}{|l|}{ mardku matrimoiety } \\
\hline A1m & na-ngarridj & $=$ & ngal-wakadj & B1f \\
\hline A1f & ngal-ngarridj & $=$ & na-wakadj & B1m \\
\hline A2m & na-burlany & $=$ & ngal-kangila & B2f \\
\hline A2f & ngal-burlany & $=$ & na-kangila & B2m \\
\hline C1m & na-wamud & $=$ & ngal-kodjok & D1f \\
\hline C1f & ngal-wamud & $=$ & na-kodjok & D1m \\
\hline D1m & na-kamarrang & $=$ & ngal-bangardi & D2f \\
\hline D1f & ngal-kamarrang & $=$ & na-bangardi & D2m \\
\hline
\end{tabular}

Source: Author's work.

The extensive set of egocentric and sociocentric terminologies allows for a wide and finely grained range in kin reckonings from the very specific to the very general. There is evidence of overt discussion of principles for mapping between the various levels of generality in reckonings in precolonial times.

Marriage practices are central to Australian kin terminologies-both egocentric and sociocentric. They are also central to the nature of mappings between reckonings at various levels. This follows from the combination of the fact that kin terminologies were understood to be conterminous with the potential social universe, and marriage was positively prescribed to particular classes of kin. Given that every person has a kin classification, if there was a wrong marriage, then this wrong marriage had extended effects for the application of the kin terminology.

By contrast, we may consider a situation in which marriage is positively prescribed to particular classes of kin, but kin terminologies are not understood to be conterminous with the social world. In this situation, a wrong marriage to somebody is not classified as kin would not necessarily have any extended effects on the application of the kin terminology. 
The non-kin spouses could simply reclassify each other to the correct kin category, and this reclassification would have no necessary effect on the kin categorisations within their existing kin networks.

Berndt and Berndt (1970) provided detailed data on Gunbalanya Bininj Gunwok marriage preferences. They distinguished a number of gradations in the legitimacy of particular marriage arrangements. Within this set of gradations, they drew an overall distinction between 'legitimate' and 'illegitimate' marriages. The category of 'legitimate marriages' involves two terms: kakkali 'spouse' and kanjok 'cousin'. Berndt and Berndt did not specifically address the linguistic analysis of these terms, but their analysis proceeded on the basis that the reference sets for kakkali and $k a n j o k$ were disjointed. They analysed kakkali as 'spouse, first preference spouse' and kanjok as 'cousin, second preference spouse'.

Garde (2013, pp. 35-8) provided an alternative analysis of the meanings of kakkali and kanjok, reporting that when asked about the meanings of the terms kakkali and kanjok, Bininj Gunwok speakers described their reference sets in terms of a superset-subset relationship. The superset is kanjok 'cousin, potential legitimate spouse', and the subset is kakkali 'actualized spouse, long-term betrothed, potential legitimate spouse who one has a high degree of claim to'.

As the ensuing discussion will demonstrate, Berndt and Berndt (1970) provided a substantial body of evidence that the achievement of a legitimate marriage often involved the weighing of various competing 'legitimate' claims to potential marriage partners. The usage of the terms kakkali and kanjok could vary in accordance with the variations in the weighing of competing claims over time. Like Garde, I analyse these variations as reflecting variations in whether a subset term, in this case kakkali, can or should be used to appropriately describe an actual or potential spousal relationship at a particular point in time. I do not analyse shifts between $k a k k a l i$ and kanjok as reflecting shifts between disjointed reference sets.

Berndt and Berndt presented the best-based marriage claim as between people who call one another kakkali, and where the husband and motherin-law classify each other as na-kurrng 'son-in-law' and ngal-kurrng 'mother-in-law':

The ideal spouse ... is a gagali [kakkali], and the ideal mother-in-law from a man's point of view is a ngalgurng [ngal-kurrng]. Relatives a man calls by the term gagali include MMBDD, FFZSD, FZDDD, and MBDDD.

(Berndt \& Berndt 1970, p. 94) 
Among these relatives, FZDDD is the preferred spouse (Harvey 2001, pp. 121-5). Berndt and Berndt (1970, p. 95) discussed this highestpreference spouse from a woman's perspective:

Women seem to emphasise the matrilineal 'side' more than men do. In general, we found that they were most likely to cite as an ideal union one in which a woman gives her first daughter to her actual mother' mother's eldest brother's eldest son, as most eligible nagurng [na-kurrng]. This trend appeared in ordinary conversations and in comments on actual cases and on myths, and in responses to the question, 'Who is your/their true nagurng?' Or in reference to children not yet betrothed, 'Who is your/ their mother's true nagurng? Where will they look for a wife/husband?'

As the quotation indicates, actual genealogical links between potential spouses favour a marriage claim. Candidates whose relationship to a potential spouse is purely classificatory are less favoured. Nonetheless, marriages with fewer favouring factors, but within the overall kanjok 'cousin' class did occur, and were overtly presented as legitimate:

In second-choice unions they are genealogically related as ganjulg [kanjok]; once they marry they call each other gagali, too, but only as a courtesy term—-they are 'not real gagali'. (Berndt \& Berndt 1970, pp. 99-100)

Berndt and Berndt (1970, pp. 100-1) presented a range of evidence that showed that actualisation of a less-favoured marriage within the overall kanjok 'cousin' class of legitimate spouses did not erase the less-favoured status of these unions:

De facto gagali and nagurng-ngalgurng are expected to behave substantially as if their bonds were 'real'- that is, as if they were based on genealogical ties. A man has the usual obligations toward his mother-in-law ... including partial avoidance, but what is uncertain is how far he and she are obliged or entitled to use the special gungurng [kun-kurrng] vocabulary in speaking together. It is the only proper medium of conversation in this affinal relationship, but ideally restricted to 'real' nagurng-ngalgurng, where the genealogical connection is traceable or implied ... Otherwise, minor departures from the ideal marriage type do not attract much notice in the ordinary way. They are most likely to come to the surface in arguments and quarrels. A husband and wife in such circumstances have a ready-made grievance that each of them can use, even after years of marriage. They can accuse each other of being only ganjulg and not real gagali, adding (for instance), 'Those [named] are my gagali-I should be married to them, not to you!' 'My mother didn't give me to you [or vice 
versa]; you're not the right husband [or wife] for me!' Accusations of the same kind are exchanged between son-in-law and mother-in-law too, but mostly indirectly in monologues, or statements addressed to the camp in general without mentioning names.

Berndt and Berndt (1970, p. 100) provided data on variations in the limitation of the kanjok class that led into consideration of marriages that were overtly characterised as 'illegitimate' to varying degrees:

In cross-cousin marriages, the timing of the betrothal is particularly crucial. If such a betrothal is confirmed quite early in a girl's life by relatives, above all by her mother and mother's brother, and preferably at the time of her birth, that in itself legitimizes it for practical purposes, but not to the extent of identifying it with the ideally correct type of marriage. However, if that opportunity lapses and no betrothal is arranged between them, the cross-cousin relationship may change as far as terms are concerned so that the two call each other by the terms for 'father' ... and 'daughter' ... (The change seems to take place usually before the girl reaches puberty). From that point on, marriage between them is regarded as wrong, but not outrageously so. We recorded a scattering of instances in early marital histories of people who were elderly in 1947, as well as in current unions. Their formal shortcomings were frankly admitted to the extent of labelling them 'wrong', but without the aura of shame and defensiveness that still surrounds 'really wrong' (for example, intra-moiety) unions.

According to information I have gathered, the use of the terms 'father' and 'daughter' is established much earlier than puberty — for actual first cousins, at least. Further, the relationship between actual first cousins using these terms is a highly constrained avoidance relationship, possibly because marriage between them remains a possibility. As such, it is quite different from an actual father-daughter relationship.

It is important to note that the overt classification of these marriages as 'illegitimate' was not limited only to people outside the marriage. The partners in these marriages also overtly classified the marriages as 'illegitimate'. In other words, individual life histories and perspectives were not a factor that affected the overt classification of marriages as 'legitimate' or 'illegitimate'.

The class of 'illegitimate' marriages was itself not uniform, but had subdivisions. Berndt and Berndt (1970, p. 61) provided further information on 'really wrong' intra-moiety unions: 
The second Gunwinggu marriage rule is that matrilineal moieties are exogamous ... This ideal has not been seriously challenged. In actuality, there have been a few instances of intra-moiety marriage in recent years. They are conventionally regarded as wrong, but in practice they are tolerated or excused, usually on the grounds that some outside influence is responsible. For example, 'This is Yiwadja custom', or the missionaries have interfered with our rules'.

Berndt and Berndt (1970, p. 64) also provided a further criterion for determining illegitimacy that involves matries:

If moiety exogamy is important to Gunwinggu, semi-moiety exogamy is far more so: it is a 'last-ditch' rule.

They did not discuss whether there were any violations of this rule, and if so, what the responses to such violations might have been. Table 9 summarises the data provided by Berndt and Berndt (1970) on the overt classification of marriages by Bininj Gunwok speakers.

Table 9: Classification of marriages by Gunbalanya Bininj Gunwok speakers.

\begin{tabular}{|l|l|}
\hline Marriage between & First preference marriage. Not overtly criticised. \\
\hline $\begin{array}{l}\text { kakkali subclass } \\
\text { of kanjok 'cousin' }\end{array}$ & $\begin{array}{l}\text { Second preference marriage. Marriage arrangements should } \\
\text { follow prototypical timing. Can always be used as a grievance. }\end{array}$ \\
\hline kakkali subclass & $\begin{array}{l}\text { Overtly categorised as wrong by partners and others. Does not } \\
\text { induce 'shame'. Not overtly described as a 'foreign' practice. }\end{array}$ \\
\hline $\begin{array}{l}\text { 'Father and daughter' were kanjok } \\
\text { Intra-moiety }\end{array}$ & $\begin{array}{l}\text { Overtly categorised as wrong by partners and others. Induces } \\
\text { 'shame'. Overtly described as a 'foreign' practice. }\end{array}$ \\
\hline Within matry & $\begin{array}{l}\text { Described as the most important taboo. No data available } \\
\text { on whether violations occurred, and if so what responses } \\
\text { violations would have encountered. }\end{array}$ \\
\hline
\end{tabular}

Source: Author's work.

The attainment of marriage everywhere in Australia was undoubtedly a complex process, extended in time and involving many individual factors (for a classic account, see Hiatt 1965). Berndt and Berndt (1970, pp. 97-9, 167-73) discussed specific betrothal and marriage processes among Gunbalanya Bininj Gunwok.

However, there is evidence that individual factors were constrained by the overtly discussed norms on marriage. Sutton (2003, pp. 148-151, 246) presented data on marriage actualisation from many areas that were less 
affected by colonialism. There were no cases in which the percentage of marriages satisfying prescriptive requirements was less than 80 per cent, and the average was 90 per cent.

Given the central importance of marriage attainment to kin terminologies, it is to be expected that overt articulations of norms about marriage would also extend to overt discussion of norms about mappings between reckonings at various levels of the egocentric and sociocentric terminologies.

Discussion of mappings was more likely to arise with finer-grained mappings. By their very nature, larger-scale categorisations and mappings offered fewer opportunities for issues to emerge. In this respect, it is interesting to note that the two larger-scale sociocentric terminologiesmatrimoieties and matries-were less flexible in their application than the smallest-scale sociocentric terminology—subsections:

Moiety and semi-moiety [matry] affiliation is fixed before birth and cannot be changed. Conventionally, this applies to subsection affiliation too, but in actual practice it is more flexible. (Berndt \& Berndt 1970, p. 73)

Harvey and Garde (2015, p. 255) discussed variable subsection affiliation in western Arnhem Land. As with marriage attainment, the existence of some flexibility does not demand that there are no norms. In the great majority of cases, subsection usage follows 'straight' usage. People can and do describe departures from standard usage as 'wrong'. Thus, if two people $\mathrm{X}$ and $\mathrm{Y}$ have the same subsection, then they should not refer to another individual $\mathrm{Z}$ with kin terms that differ on the cross versus parallel distinction or the harmonic versus disharmonic generation distinction. If $\mathrm{X}$ calls $\mathrm{Z}$ by a parallel harmonic term such as 'brother', then $\mathrm{Y}$ should not call $Z$ by a cross-term such as 'cousin' or a disharmonic term such as 'father'. If this does occur, then $\mathrm{X}, \mathrm{Y}, \mathrm{Z}$ and other people will all overtly agree that there is something 'wrong' somewhere.

\section{Land Tenure Terminologies}

In the period from 1947 to 1990, two name terminologies were used in discussions of land tenure: language name terminologies and a name terminology most commonly known as 'gunmogurrgurr'. The gunmogurrgurr terminology itself has a range of names in the languages of the area (see Table 10). 
Table 10: Gunmogurrgurr terminology in the languages of the area.

\begin{tabular}{|l|l|}
\hline Amurdak & Iwurrumu \\
\hline Eastern Bininj Gunwok & gun-nguya \\
\hline Western Bininj Gunwok & gun-mogurrgurr \\
\hline Iwadja & nguya, yiwurrumu \\
\hline Jawoyn & mowurrwurr \\
\hline Mawng & namanamaj \\
\hline
\end{tabular}

Source: Author's work.

There is also a third terminology that relates to land. In Bininj Gunwok, this terminology is known as 'yigurrumu'. This name evidently relates to the Amurdak and Iwaja equivalents '(y)iwurrumu' of Bininj Gunwok 'gun-mogurrgurr/gun-nguya'. The yigurrumu terminology did not appear to have been used in discussions of land tenure. Nonetheless, I examine it here, because its lack of usage is in itself a matter of interest.

Language name terminologies were used in discussions of land tenure throughout the region and Australia. As in other regions in Australia, the scale of the area of land to which particular language names were attached could vary greatly. Some areas of land were associated with more than one language name. All cases known to me in the northern Kakadu - Gunbalanya area involved names of significantly different scales. Discussions of land tenure at a more general level tended to use larger-scale language names, while discussions of land tenure at a more specific level tended to use gunmogurrgurr names. The gunmogurrgurr terminology had a more limited geographical range than did the language name terminology. All areas associated with the Bininj Gunwok, Gaagudju and Ngaduk language names were also associated with gunmogurrgurr names at a smaller scale. As we will see in the section 'The Effects of Colonisation on Land Tenure', gunmogurrgurr terminology did not appear to be associated with the areas west of the areas related to Bininj Gunwok, Gaagudju and Ngaduk. It was not found in areas associated with Limilngan, or in areas associated with Bugurnidja, Ngombur and Umbugarla. It is not known whether gunmogurrgurr terminology was found in areas associated with Gonbudj.

Land-language associations were comparatively straightforward in the northern Kakadu - Gunbalanya area. All language names were associated with contiguous sets of sites. No language names were discontinuously 
associated. ${ }^{1}$ For smaller-scale names, there was agreement pertaining to the set of sites associated with that name. This was also the case for most larger-scale names. I encountered only one situation in which there was variation in the geographical extension of a larger-scale language name. This was the term 'Mayali'. Everybody agreed that the area associated with Gundjeihmi was also associated with Mayali. People varied in opinion as to whether areas associated with Kunwinjku were also associated with Mayali.

The gunmogurrgurr terminology had a different internal structuring. Gunmogurrgurr names were commonly associated with discontinuous areas of land. Consequently, some gunmogurrgurr names, such as Mirarr, are associated with large areas, whereas others, such as Manilagarr, were associated with small areas. However, unlike language names, there was no distinction in scale among gunmogurrgurr names. ${ }^{2}$ All gunmogurrgurr names were incompatible with one another. It was not possible for a single area of land to be associated with a 'small scale' gunmogurrgurr name and also a 'large scale' gunmogurrgurr name. A particular area of land could only be associated with one gunmogurrgurr name.

Given that two structurally distinct terminologies were used to discuss land ownership, it would be a reasonable hypothesis that reconstructions involving these terminologies should parallel the reconstructions for kin terminologies - that is, there would be evidence to reconstruct the mappings between the two systems and criteria for evaluating the mappings as precolonial topics of overt discussion. However, this is not the case. There is no evidence for the reconstruction of overt discussion on these issues. This can be illustrated by considering the associations of the Mirarr gunmogurrgurr name in the northern Kakadu - Gunbalanya area (see Figure 16). The Mirarr name was associated with six distinct estates and five different language names: Amurdak, Erre, Gaagudju (two distinct areas), Gundjeihmi and Urningangk (Harvey 2002b). With one

\footnotetext{
1 The one apparent exception is discussed in the section 'The Effects of Colonisation on Land Tenure' of this chapter.

2 Berndt and Berndt (1970, p. 55) stated that 'some gunmugurgur [gunmogurrgurr] are "bigger" than others and can subsume smaller names in the same large territory. For instance, Djelama is a "big" gunmugurgur and Nguluminj is a minor one'. Berndt and Berndt did not provide details on the territorial associations of Djelama and Nguluminj, but they were not associated with the northern Kakadu - Gunbalanya area. They are most probably Kunwinjku names from further to the east of Gunbalanya. Without more information, it is not possible to assess the description that Berndt and Berndt provided. Whatever the details of their associations, it does not alter the fact that in the northern Kakadu - Gunbalanya area gunmogurrgurr names are incompatible with one another.
} 
exception, the conjunction of a language name and a gunmogurrgurr name would suffice to distinguish each estate. This is the case generally throughout western Arnhem Land-the conjunction of a language name and a gunmogurrgurr name commonly distinguishes an estate.

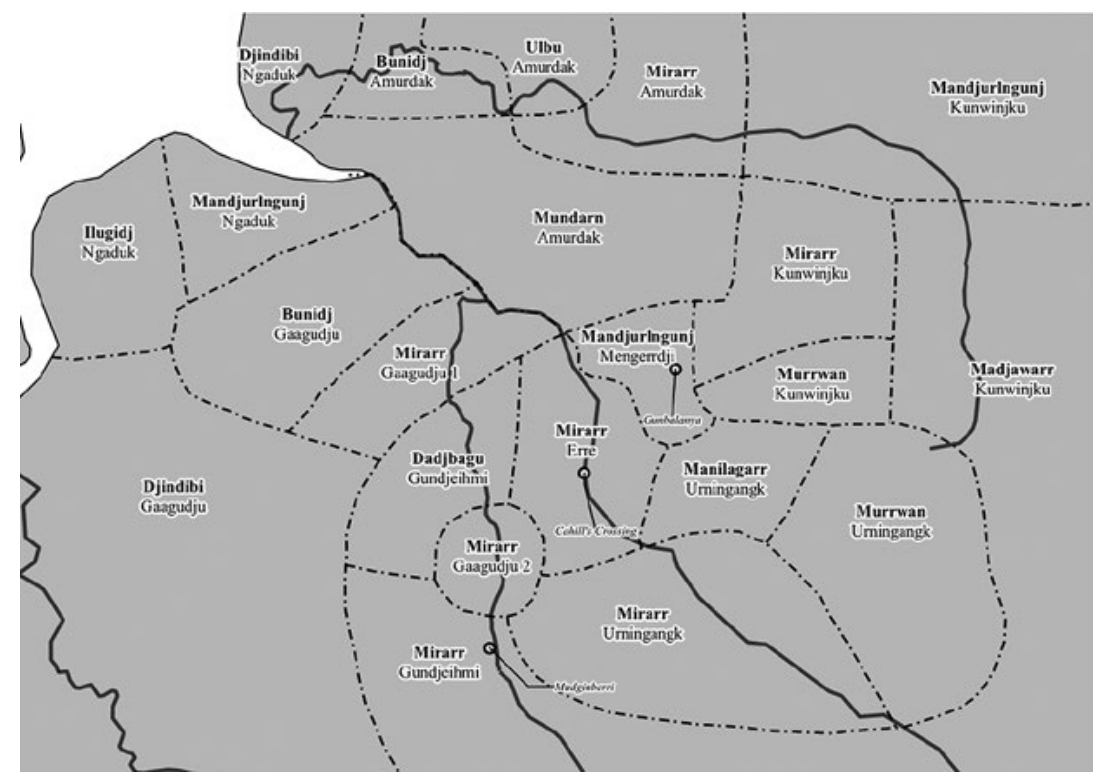

Figure 16: Gunmogurrgurr names in the northern Kakadu - Gunbalanya area.

Source: Harvey (2002, p. xvi).

I discussed land tenure extensively with a range of knowledgeable Indigenous consultants in the period from 1986 to 1989 (five field trips totalling 12 months). All these consultants had been extensively involved with land claims in the period preceding my fieldwork. A discussion about Indigenous land tenure was not an unprecedented activity for any of them, nor was a discussion about areas of land whose ownership was less than straightforward. However, none of these experienced consultants ever conjoined language names and gunmogurrgurr names in such a way as to clearly discriminate one estate from another.

The consultants did not use compound terms such as Mirarr-Amurdak or Mirarr-Gaagudju. They did not produce sentences such as 'This lot Mirarr, they got Amurdak language. That nother lot Mirarr, they got Gaagudju language'. This was even the case when discussions focused 
specifically on distinguishing different Mirarr estates. There was, in fact, no linguistic evidence that they conceived of language names and gunmogurrgur names as having any kind of mapping relationship.

The same lack of evidence for a mapping relationship is found in the yigurrumu terminology. The yigurrumu terminology differs from the gunmogurrgurr and language terminologies in that its members are not fundamentally referential. Berndt and Berndt (1970, p. 54) provided the following information on yigurrumu:

Each territory is associated with a named unit of patrilineal descent, the gunmugurgur [gunmogurrgurr] ... In turn, each of these is linked with another name that is much less widely known. This is the igurumu [yigurrumu] or ngwoia [gun-nguya] ${ }^{3}$ (Eastern Gunwinggu), a stylised exclamation that is used also in ritual invocations and therefore sometimes said to be bigger, more important, than the gunmugurgur name.

According to the consultants, the yigurrumu names should be cried out when someone sneezed. Keen (pers. comm.) reported that they should be cried out when someone was in danger. The significance of these various usages requires further consideration. However, overall, it is evident that the yigurrumu terminology is an exclamatory, and not a referential, terminology.

Nonetheless, the consultants categorised yigurrumu terms as 'names' and conceived of them as being critically anchored in estates. Therefore, one reasonable hypothesis would be that consultants might refer to yigurrumu names in the context of discourses focusing on clarifying uncertainties about land ownership. This is particularly relevant if yigurrumu names are generally distinctive of specific individual estates.

During the time of my fieldwork from 1986 to 1989, the yigurrumu terminology was less well known than the language name or gunmogurrgurr terminologies. Consequently, I could not obtain complete data on the terminology. The available data are set out in Table 11.

3 The 'ngwoia' term used by Berndt and Berndt appears to be the -nguya portion of the word 'gunnguya'. As discussed, this is the Eastern Bininj Gunwok equivalent of the Western Bininj Gunwok term 'gun-mogurrgurr'. The Berndts' description implies that 'gun-nguya' is the equivalent for both 'gun-mogurrgurr' and 'yigurrumu'. This is not the case; 'gun-nguya does not include 'yigurrumu' within its reference, and the term 'yigurrumu' is used by Eastern Bininj Gunwok speakers. 
Table 11: Yigurrumu terminology.

\begin{tabular}{|l|l|l|}
\hline Gunmogurrgurr & Language & Yigurrumu \\
\hline Bunidj & Amurdak & Arnbalarr, Imbini \\
\hline Bunidj & Gaagudju & Mananawangaardi, Galbarraarru, Manabuudja \\
\hline Djindibi & Amurdak & Marniyalga \\
\hline Djindibi & Gaagudju & Garlangeebu \\
\hline Mandjurlngunj & Mengerrdji & Magalirra \\
\hline Mandjurlngunj & Ngaduk & (?) Muwarl \\
\hline Madjawarr & Gunwinjgu & Djambunu, Nabamgarrk \\
\hline Mirarr & $\begin{array}{l}\text { Amurdak } \\
? \text { \& Gunwinjgu }\end{array}$ & Djambunu, Nabamgarrk \\
\hline Mirarr & Gaagudju (1 \& 2) & Gamadaagu \\
\hline Mirarr & Gundjeyhmi & Ginjmardamba \\
\hline Manilagarr & Urningangk & Winjbet, Manila \\
\hline Ulbu & Amurdak & Injgurr, Wadjarra \\
\hline
\end{tabular}

Source: Author's work.

A couple of cases are highlighted in Table 11 in which yigurrumu names are shared between two estates; otherwise, yigurrumu terms are distinctive of individual estates. Given that yigurrumu terms are not referential, there would be no reason to predict that consultants would use compound terms such as Bunidj-Arnbalarr versus Bunidj-Mananawangaardi. However, it is a reasonable prediction that they might produce sentences such as 'This lot Bunidj, they got Arnbalarr name. That nother lot Bunidj, they got Mananawangaardi name'. Consultants did not do this, and there was no linguistic evidence that they conceived of any systematic mapping relationship between yigurrumu terms and the gunmogurrgurr or language name terminologies.

This lack of evidence for any systematic mapping between the gunmogurrgurr, language name and yigurrumu terminologies was part of a more general lack of evidence for overt discussion over detailed discrimination in land tenure. The lack of precision in discriminating estates from one another is matched by the lack of precision in other important areas, such as the inheritance of land tenure and the nature of relations between clans (the group of owners of an individual estate).

Both gunmogurrgurr and language names were inherited patrifiliatively. They could be inherited from pater and genitor: 
Patrilineal descent is the conventional basis of gunmugurgur [gunmogurrgurr] membership, but social paternity may affect it. For example, a child may adopt the gunmugurgur affiliation of a stepfather who rears him, especially if he is very young when his own father died, or he may later claim dual affiliation from 'both his fathers'. (Berndt \& Berndt 1970, pp. 55-7)

However, there is no evidence for any more systematic discussion of either the provision for inheritance from pater or the dual affiliation option.

While primary ownership is inherited patrifiliatively, people also have rights to their mother's estate and other estates. Berndt and Berndt (1970, p. 54) observed that 'other associations are recognised, too: for instance, with a person's mother's country (which is also her father's) and with her mother's country'. In Gaagudju, there is a term guwaaluwa that means 'mother's country'. This root takes a prefixation to indicate the propositus, such as ngadj-guwaluwa (1sg-mother's country) 'my mother's country'. In Bininj Gunwok, there is a range of terms for 'mother's country' and a term for 'mother's mother's country' (Garde pers. comm.) (see Table 12).

Table 12: Ways of referring to mother's and mother's mother's country.

\begin{tabular}{|c|c|}
\hline -bo-garrang & nga-/birri-bo-garrang \\
\hline -water-mother & 1 sg-/3pl-water-mother \\
\hline 'mother's country' & 'my/their mother's country' \\
\hline karrard-warre-ken & kakkak-warre-ken \\
\hline mother-bad-GEN & MM-bad-GEN \\
\hline 'mother's country' & 'grandmother's country' \\
\hline \multicolumn{2}{|c|}{ kun-warddjak/-mirrirn } \\
\hline \multicolumn{2}{|l|}{ IV-warddjak } \\
\hline $\begin{array}{l}\text { 'a person whose m } \\
\text { gunmogurrgurr na }\end{array}$ & Warddjak/Mirrirn \\
\hline
\end{tabular}

Source: Author's work. 
However, there is no evidence for overt discussion on the more precise delimitation of rights to estates other than the patrifiliative estate. For example, did individuals have inalienable rights of residence and foraging over their mother's country? Keen (1994, p. 125) made the following observation on precisely this point in relation to north-east Arnhem Land:

In the recent pre-colonial past, conflict among men over the control of country and its resources were probably linked mainly to competition over women and the control of ceremonies, for the non-exclusivity of rights in food resources of country and the flexibility of residence made it unlikely that there were great quarrels over access to those food resources unless major anomalies arose in the relations between the size of groups and country.

An absence of a more precise delimitation is also found when considering relationships among clans, and here we may return to the Mirarr example previously discussed. Does the sharing of the Mirarr name by six clans indicate some kind of systematic relation between these clans? Based on the available evidence, there is no such systematic relationship.

In the period from 1970 to 1990 , people commonly described various clans - both those sharing gunmogurrgurr names and those with different gunmogurrgurr names - as 'company'. However, there were no systematic correlations to this 'company' description:

The majority of these [company] relationships are not corporate, but personal, they are not relationships between clans, but between individual members of clans ... The content of [these] company relations varies greatly'. (Levitus 1987, pp. 32-3)

In my own research, responses to questions on an issue such as whether people who shared a gunmogurrgurr name were necessarily co-owners of some kind included 'yes', 'no' and 'yes and no'. For example, when I asked one senior Mirarr estate owner whether the owner of another adjacent Mirarr estate was the same or different to him, he replied, 'Oh different one, but we still same little bit, my cousin'. There was no evidence that the sharing of a gunmogurrgurr name had ever constituted an issue requiring systematic and overt discussion.

The lack of evidence for reconstruction of overt discussions over detailed discrimination in land tenure contrasts strongly with the situation for kin terminologies. As we have seen, there is evidence for the reconstruction of overt discussions over detailed discrimination in kin terminologies, and in the mapping between them. 
I suggest that this difference in reconstructions correlates with the significant difference between the two domains in the extent to which they were overtly recognised as motives for disputation. The available data support a reconstruction in which kinship, marriage and sexuality were commonly presented as causes of precolonial disputes:

Gunwinggu themselves, including women, often cited 'women and corpses' as the outstanding causes of conflict, in mythical or quasimythical as well as contemporary situations. Old Mangurug suggested that the reason the Woraidbag are virtually extinct was that they were always fighting over women-not over dead men and their killers, but only over women. That's why all of them are dead and their country is empty of people. If we had done the same, we would all be gone now, too'. (Berndt \& Berndt 1970, p. 167)

By contrast, there is no evidence that land tenure was commonly presented as an overt cause of disputes. Determining the overall or ultimate causation of disputes is always a fraught exercise. Recognition of differences between overtly presented motives, as opposed to covert and/or inchoate motives, is probably a universal of human cognition. In the case of land tenure, colonisation presents a particular problem. One of the most immediate effects of colonisation was the imposition of Pax Australiana, even in areas where the effects of colonisation were much less. As such, data on disputation from even the earliest periods of colonisation require careful consideration when attempting to reconstruct the precolonial past. The issue of whether land tenure might have been a covert and/or inchoate motive for disputation in precolonial times may not be a resoluble issue.

The opposition in overt presentation of causality between the domains of kinship and land tenure generally appears to hold across Australia. Some analysts present the difference in terms of land tenure not having a causal role. Warner (1964 [1937], pp. 18-19) provided the classic statement of this nature:

No land can be taken from a clan by an act of war. A clan does not possess its land by strength of arms but by immemorial tradition and as an integral part of the culture. Murngin myth dies hard, and ownership

4 It is of interest to note that the Woraidbag (Wardadjbak-which is the Bininj Gunwok term for Amurdak) were not virtually extinct at the time of the Berndts' fieldwork. Up until the late 1960s and early 1970s, there were direct patrifiliates for every known Amurdak estate. However, these patrifiliates were not normally resident in the Gunbalanya area. Despite this lack of residence, all these Amurdak patrifiliates would have been known to significant numbers of people who were long-term residents of Gunbalanya at the time of the Berndts' fieldwork. 
of land is in Murngin myth even after the final destruction of a particular clan. It would never occur to a victorious group to annex another's territory, even though the entire male population were destroyed and the dead men's women and children taken by the victors. In the passage of time the clan using it would absorb it into their own territory and the myth would unconsciously change to express this. In the thought of the Murngin, land and water, people and clan are an act of the creator totem and the mythological ancestors, who always announce in myth and ceremony that this is the country of such and such a clan; to expropriate this land as a conscious act would be impossible. Just as the totem, the creator, and the members are a permanent and inextricable part of the culture, so is the clan's ownership of the land.

Hiatt (1965, p. 16) agreed with Warner:

Disputes over land did not arise, and it was therefore difficult to discover the attitudes of owners towards their estates. I judged that they had an intimate knowledge of their sites and the country included by them but proprietorial interest outside this central core progressively weakened.

\section{Stanner (1979, p. 233) further supported Warner:}

That is not to say there were never occasions on which whole groups were put to the spear, or that there was no lasting bad blood between groups at enmity. It was often so, especially when, by migration or some other cause, neighbour tribes spoke unrelated tongues, or had very distinct customs. But the conquest of land was a great rarity: I do not personally know of a single case. And the war of extermination, with one group bent remorselessly on the complete destruction of the other, as far as I have discovered, was so rare as to be all but unknown.

Sutton (1978, pp. 77-8) presented a slightly different perspective:

I am not aware of any cases where land has changed hand by acts of war, although I am told that some massacres long ago resulted in clan extinction. I see no reason why this could not happen, however. I do not accept Warner's argument, relating to northeast Arnhem land (1964, pp. 18-19), which says that expropriation of land by acts of war is impossible because tenure is based on mythic charter, and these charters only change unconsciously to express changes of possession. I suggest it would take only a generation or two for mythic charters to be consciously re-written in such cases, and that the memory of massacres would be suppressed just as consciously. It is true, however, that battles were not waged just for the purpose of conquering and settling new lands as has often been the case in other parts of the world. 
While Sutton disagreed with Warner as to the potentiality for speed and deliberateness of change in land tenure, he agreed that disputes were not fought over land in and of itself. Keen (2004, p. 266) concurred with Sutton's viewpoint in his presentation of north-east Arnhem Land.

Yolngu oral history includes some accounts of expansionist individuals who fought for the country and the women of other groups. This kind of aggression was linked to competition between men for marriage to the same women, and hence to polygyny.

Therefore, overall, the reconstruction of a difference in the overt presentation of kinship and land tenure as motives for disputes is well supported by the evidence from across Australia. As discussed, a reconstruction of the full range of causality, including covert and/or inchoate motives, in disputation is a very different matter and not one considered here. Given that land in and of itself was not overtly presented as a cause of disputes, it appears that indeterminacies and inconsistencies in this arena were only rarely forced to the forefront in discourses among Aboriginal people.

\section{The Effects of Colonisation on Land Tenure}

The effects of colonisation have been most prominent in relation to land tenure. Land ownership is at the core of colonisation, which fundamentally involves the expropriation of other people's land. The northern Kakadu - Gunbalanya area was one of the areas less affected by colonial expropriation in Australia. Land was not expropriated into private hands, but theoretically remained the property of the Australian government. When the Land Rights Act was passed in 1976, the northern Kakadu area became available for claim.

However, the claim process was not straightforward. As previously discussed, although colonisation did not result in effective expropriation of the land, it decimated the populations traditionally associated with the northern Kakadu area. Further, as a result of engagement with colonial economic regimes, the residential ranges of the great majority of people associated with the northern Kakadu area were focused further to the west, closer to Darwin during the period from 1920 to 1970, and possibly even earlier than 1920 . 
Consequently, by the time the land claim process started in the 1970s, knowledge of land tenure had been attenuated. Even the most knowledgeable people had gaps in their understanding, and the knowledge base of any one individual generally failed to match the knowledge bases of any other individual. The problems of dealing with this attenuation were significantly exacerbated by the fact that there was no recognised or remembered system for overt discourse on indeterminacies in land tenure. Nevertheless, based on research with the most knowledgeable consultants in the 1970s and 1980s, it was possible to reconstruct a relatively coherent overview of land tenure at colonisation (see Figure 16).

However, there is an anomaly in Figure 16. The Mirarr-Gaagudju 2 estate is not contiguous with the other Gaagudju estates. As discussed, language names do not show a discontinuous attachment to the land in this area. In this particular instance, there is evidence that the Gaagudju language name can be reconstructed with contiguous associations. Specifically, there is evidence that the Dadjbagu estate, which is listed as associated with Gundjeyhmi, is historically associated with Gaagudju. The most direct evidence for this comes from a number of placenames in the Dadjbagu estate: Ardaagawa [adáakəwa], Garraanggirr [garáangır] and Goordawu [góodauu]. The phonetics and phonology of these names are incompatible with Bininj Gunwok (Evans 2003a, pp. 72-105), but perfectly compatible with Gaagudju (Harvey 2002a, pp. 17-92).

Complementing these findings is evidence from placenames that show that the association of Gaagudju with the Mirarr-Gaagudju estate is not of recent origin (see Table 13).

Table 13: Analysis of place names.

$\begin{array}{lll}\text { Ma-ya-bardeedj=madjiirli } & \text { Djaa-yu } & \text { Mooyu } \\ \text { 3IIIA-PR-?=sand } & \text { PR-lie } & \text { sore } \\ \text { 'The sand, it Xs' } & \text { 'The sore lies' } & \end{array}$

Source: Author's work.

The name Ma-ya-bardeedj=madjiirli is a compound, of a rare type with limited productivity (Harvey 2002a, pp. 131-4). The noun madjiirli 'sand' is a Class III noun, and ma-ya- is the appropriate present tense prefix complex for an intransitive verb with a Class III subject. However, my consultants did not recognise the bardeedj constituent. The Djaa-yu Mooyu placename is irregular. The noun mooyu is a Class III noun, and the 
regular construction for 'The sore lies' would be Ma-yaa-yu Mooyu. It is a recognised principle of internal reconstruction that irregularities that are not themselves the result of horizontal transmission indicate a greater time depth, with the corollary that the greater quantity of irregularity, the greater the time depth (Campbell 2006, p. 230; Crowley \& Bowern 2010, p. 125; Ringe 2003, p. 254; Seebold 1975, p. 157).

The evidence from placenames argues that the association of Gundjeyhmi with the Dadjbagu estate is of recent origin. The available evidence on land ownership is congruent with this proposal. In the early twentieth century, eight to nine people in two ostensibly distinct patrilines were primary owners of the Mirarr-Gaagudju 2 estate. There was only one owner for the Dadjbagu estate at this time. A change of ownership involving a change of language affiliation is much more plausible in the situation in which there is a single owner, than in the case of eight to nine owners.

Further, it is not certain that the discontinuity ever had an on-the-ground reality. The anomaly may, in fact, be an artificial effect of colonisation. As discussed, this area was effectively depopulated by 1920 . The known histories of owners of the Dadjbagu estate and the Mirarr-Gaagudju 2 estate establish that none of them were normally resident in the northern Kakadu area after 1920, and possibly from an earlier date. If they had been resident, then a more usual process might have taken place. The sole owner of the Dadjbagu estate in the early twentieth century would have changed his primary language affiliation to Gaagudju because the estate was associated with Gaagudju.

The apparent discontinuity in Gaagudju land-language associations is a prototypical example of the indeterminacies and contradictions in geographically based knowledge that often follow the effects of colonisation. This attenuation of geographically based knowledge is not limited to uncertainties pertaining to the associations of particular areas. It also extends to indeterminacies and contradictions concerning the geographical limits of land tenure systems. In this case, the indeterminacies and contradictions involve the extent of the gunmogurrgurr name system. Keen (1980, p. 80) reported evidence that the gunmogurrgurr terminology did not extend to areas associated with Bugurnidja, Ngombur and Umbugarla precolonially:

I found that people were inconsistent and hesitant in their use of the kunmokurrkurr names Wirlirrku, Marerrmu and (to a lesser extent) Murumburr ... People were consistent however in their use of the 
language-group names Bukurnidja, Mbukarla and Ngombur. Older people of the Mbukarla and Ngombur language-groups said that really they had no kunmokurrkurr, but the Mayali (Kundjey'mi) people imposed the category on them.

I encountered the same extension of the gunmogurrgurr terminology, although on a more idiosyncratic basis, in work with Nelson Mulurrinj, who in the late 1980s was recognised as a senior landowner in the Cobourg Peninsula area to the north of Amurdak. Nelson had lived for extended periods of time in and around Darwin, and had extensive life history contacts with a range of people whose primary landownership was to areas west of the South Alligator River. During a discussion on clans and clan membership in the Kakadu - Gunbalanya area (which it should be noted was largely in accord with discussions with other consultants), Nelson gave gunmogurrgurr names for people known to him, traditionally associated with the Adelaide and Mary river areas immediately to the west of Kakadu National Park. Not only did Nelson assign these people a gunmogurrgurr name, but the names were also from his area.

I have worked extensively with the traditional owners of the Adelaide and Mary River areas, and there is no evidence for the operation of the gunmogurrgurr name system among them. Indeed, to the contrary, based on discussions with senior Limilngan owner Lena Henry, it appeared that Limilngan owners discussed smaller-scale land tenure primarily in terms of totemic entities. Thus, there was a madlingi minyayan 'mature male antilopine wallaroo' country and group of owners. This system of discussing smaller-scale land tenure with a totemic terminology was also found further to the west. It was also used in areas associated with Gulumoerrgin, the language associated with Darwin and its immediate surrounds.

The effects that have been discussed thus far are not structural, and they have not changed the options for discussing land tenure. By contrast, the land claim process has provided an opportunity for the development of a structural change. In this process, compound names consisting of a gunmogurrgurr name and a language name (e.g. Mirarr Erre or Mirarr Gundjeyhmi) were used by European researchers working in the land claim process (Keen 1980). As indicated, these names were used to distinguish estates from one another, as gunmogurrgurr names could not do so on their own. These compound names continue to have some level of usage by people who are frequent users of more formal registers, as in the following Department of the Environment (2013) announcement: 
The Gundjeihmi Aboriginal Council in the Northern Territory will receive $\$ 216,000$ to document the significant Indigenous heritage sites in Mirarr Gundjeihmi country, to develop management plans and to assist in the transfer of cultural knowledge from local elders to the next generation.

However, compound names are not used by people who are not frequent users of more formal registers. Consider the following statement from the Gundjeihmi Aboriginal Corporation website (2017) for the 'Mirarr Gundjeyhmi' clan.

Gundjeihmi Aboriginal Corporation is an organisation established, managed and controlled by the Mirarr.

The use of the term 'Gundjeihmi' to describe a corporation of 'Mirarr' owners is obviously predicated on there being some intersection between the two names. However, the two are not conjoined in an individually identifying manner. In the recent past, at least, it was widely understood that there were people who owned the names 'Gundjeihmi' and 'Mirarr' who were not members of the 'Mirarr Gundjeyhmi' clan. In general, it appears that Aboriginal people and others continue to use gunmogurrgurr names alone as identifiers in discussions of land tenure.

However, it should be noted that although people do not use compound terms, such as 'Mirarr Gundjeyhmi', they do recognise the reference of these terms when those terms are used by others. In my own research, I used these compound terms, and all the people I discussed these issues with recognised that 'Mirarr Erre' was distinct from 'Mirarr Gundjeyhmi'. This suggests that, depending on the requirements for precision, compound terms could come to have a more extensive usage. Requirements for precision are in turn likely to be strongly affected by the degree of disputation over land tenure.

\section{The Effects of Colonisation on Kinship}

The effects of colonisation on kinship appear to have played out over a longer time frame than its effects on land tenure. The most significant period of change appears to have been the 1960s. Prior to the 1960s, people's daily lives had some significant elements of continuity with the precolonial past. People associated with the northern Kakadu Gunbalanya worked mostly in the pastoral industry. The majority of people at any particular site were Aboriginal people, and daily residential 
groupings were small. Most Aboriginal co-residents were longstanding consociates with various kinship links. There was significant movement across country during the annual cycle. Among the people who had become adults by the 1960s, nearly all spoke various Aboriginal languages. They could all describe traditional marriage arrangements, and many described their own participation in such arrangements.

During the 1960s, the employment structure of the pastoral industry changed radically. The great majority of Aboriginal people ceased to work in the industry, and their daily lives became focused in urban areas. In my own research, I did not record any accounts of traditional marriage arrangements after the 1960s. To the west of the Kakadu area, towards Darwin, Kriol became the principal daily language. One immediate consequence of these changes is that many younger people had only limited or no knowledge of more esoteric kinship terminologies, such as trirelational terminologies.

There is another less obvious but more significant effect on kinship terminologies in Kriol. Consider the following entries from the KriolEnglish Dictionary (Lee 2007).

andi Usage: Location: F. Variant: anti. n. father's sister, aunt. Usage: Location: BFN. Etym: aunty. SD: B. [Note: some include mother's sister $\mathrm{BW}$ and also most skin groups]

mami Synd: mam. $n$. 1) mother; mother's sister; any person in the same skin group as one's mother. Usage: Location: FN. SD: B. [Note: both vocative and reference] 2) mother's cousin. Usage: Location: F. SD: B.

It may be noted that there is variation in how 'mother's sister' is classified. Some speakers classify her as 'mother'. This is the classification in all Aboriginal language terminologies, as these all involve parallel sibling merger. However, some speakers classify her as 'aunt', which in Aboriginal language terminologies only refers to the 'father's sister'. I found this shift towards English classifications to be common among people whose residential ranges were closer to Darwin. I also found that many people accepted both usages, but only actively used the English meaning.

The extent and nature of this shift needs further research, as do the implications for mapping between egocentric and sociocentric terminologies. In this respect, I have found that sociocentric terminologies have very little active usage around Darwin. People born before 1960 
usually have a good command of sociocentric terminologies if asked about them, but they do not actively use them. Further research on the knowledge of people born after 1960 is required.

\section{Conclusion}

There is evidence that overt discussion of marriages in terms of a finegrained categorisation of 'rightness' and 'wrongness' can be reconstructed precolonially as a common practice for the northern Kakadu - Gunbalanya area. This overt discussion necessarily entails discussion of the principles for determining the details of kinship terminologies, and overt discussion of the principles for mapping between the various terminologies. In terms of Bourdieu's (1977) analysis, kinship was very much in the universe of the discussed. By contrast, there is no evidence that overt discussion of the details of land ownership terminologies was a common practice, nor any evidence for overt discussion of principles governing mapping between the various terminologies. As such, land tenure lay largely in the universe of the undiscussed.

Colonisation greatly altered both practices and overt discussion patterns. The alterations following from colonisation played out most strongly from the 1960s, as this was the most significant period of postcolonial change. After the 1960s, kinship became a less prominent framing factor for many marriages, and Kriol became the standard daily language for many people. There is evidence of a shift towards English classifications in the Kriol of many people, and it is possible that there are rather variable understandings of Kriol kin terms. As such, it is possible that one effect of colonisation has been to make kinterm usage, and the mapping between various kin terminologies, less specific and detailed than it was precolonially.

Conversely, given that land tenure is one of the prime flashpoints of colonialism, and given the development of 'land rights' in the 1960s and 1970 s, people in the period from the 1960s onwards were suddenly faced with more detailed and frequent examination of land tenure than had been the case previously. As people did not have a background in the formulation of opinions on indeterminacies within terminologies, or relationships between terminologies, the development of greater specificity in land tenure has not been speedy. The gunmogurrgurr name and language name compounds provide greater specificity, and although their active usage is 
largely confined to formal contexts and non-Aboriginal people, Aboriginal people show an immediate passive competence in these compounds. It appears that the future usage of these compounds will depend chiefly on the need for precise opinions in discussions of land tenure.

The need for precise opinions appears to relate most directly to the degree of disputation in the domains covered by particular terminologies. Precolonially, kinship (not land tenure) was the immediate topic of significant disputation. Consequently, offering more precise opinions can be reconstructed as a characteristic of discussions on precolonial kinship terminologies, but not of precolonial land tenure terminologies. Colonisation has to some extent reversed this. Land tenure (not kinship) has been the immediate topic of significant disputation. Consequently, there has been some increase in the offering of more precise opinions on land tenure terminologies, at least in specifically intercultural domains such as the land claim process, whereas kinship terminologies for many Kriol speakers appear to be less precisely defined than those found in Aboriginal languages.

\section{References}

Berndt, R \& Berndt, C 1970, Man, land and myth in north Australia: the Gunwinggu people, Canberra: Aboriginal Studies Press.

Bourdieu, P 1977, Outline of a theory of practice, Cambridge: Cambridge University Press. doi.org/10.1017/CBO9780511812507.

Campbell, L 2006, Historical linguistics: an introduction, Edinburgh: Edinburgh University Press.

Crowley, T \& Bowern, C 2010, An introduction to historical linguistics, Oxford: Oxford University Press.

Department of the Environment 2013, Announcement, viewed 1 August 2017, www.environment.gov.au/minister/burke/2013/mr 20130301.html.

Evans, N 2003a, Bininj Gunwok: a pan-dialectal grammar of Mayali, Kunwinjku and Kune, Canberra: Pacific Linguistics. 
Evans, N (ed.) 2003b, The Non-Pama-Nyungan languages of northern Australia: comparative studies in the continent's most linguistically complex region. Canberra: Pacific Linguistics.

Garde, M 2013, Culture, interaction and person reference in an Australian language: an ethnography of Bininj Gunwok communication, Amsterdam \& Philadelphia: John Benjamins. doi.org/10.1075/clu.11.

Gundjeihmi Aboriginal Corporation 2017, GAC, viewed 1 August 2017, www.mirarr.net/gac.html.

Harvey, M 2001, 'Oenpelli Kunwinjku kinship terminologies and marriage practices', Oceania, 72, pp. 117-42. doi.org/10.1002/ j.1834-4461.2001.tb02776.x.

Harvey, M 2002a, A grammar of Gaagudju, Berlin \& New York: Mouton de Gruyter. doi.org/10.1515/9783110871289.

Harvey, M 2002b, 'Land tenure and naming systems in Aboriginal Australia, The Australian Journal of Anthropology, 13, pp. 23-44. doi.org/10.1111/j.1835-9310.2002.tb00188.x.

Harvey, M \& Garde, M 2015, Matries and subsections: bodies and social personae in northern Australia, Anthropological Linguistics, 57, pp. 229-74. doi.org/10.1353/anl.2016.0006.

Hiatt, L 1965, Kinship and conflict: a study of an Aboriginal community in northern Arnhem Land, Canberra: Australian National University Press.

Keen, I 1980, Alligator rivers stage II land claim, Darwin: Northern Land Council.

Keen, I 1982, 'How some Murngin men get ten wives: the marital implications of matrilateral cross-cousin structures', Man (n.s.), 17, pp. 620-42.

Keen, I 1994, Knowledge and secrecy in an Aboriginal religion, Oxford: Clarendon Press.

Keen, I 2004, Aboriginal economy and society: Australia at the threshold of colonization, Melbourne: Oxford University Press. 
Lee, J 2007, Kriol-Ingglish dikshenri, ausil.org/Dictionary/Kriol/indexenglish/index.htm.

Levitus, R 1987, Gagudju Association membership, Report to the Gaagudju Association.

Merlan, F 1988, 'Gender in Aboriginal social life: a review', in R Berndt \& R Tonkinson (eds), Social anthropology and Australian Aboriginal studies, Canberra: Aboriginal Studies Press, pp. 17-76.

Ringe, D 2003, 'Internal reconstruction', in B Joseph \& R Janda (eds), The handbook of historical linguistics, Maldon, MA: Blackwell, pp. 244-61. doi.org/10.1002/9780470756393.ch3.

Seebold, E 1975, 'Archaic patterns in the word formation of early Germanic languages', Transactions of the Philological Society, 74, pp. 157-72. doi.org/10.1111/j.1467-968X.1975.tb01170.x.

Stanner, WEH 1979, White man got no dreaming: essays 1938-1973, Canberra: Australian National University Press.

Sutton, P 1978, Wik: Aboriginal society, territory and language at Cape Keerweer, Cape York Peninsula, Brisbane: University of Queensland.

Sutton, P 2003, Native title in Australia: an ethnographic perspective, Cambridge: Cambridge University Press. doi.org/10.1017/CBO 9780511481635 .

Warner, WL 1964 [1937], A black civilization: a social study of an Australian tribe, New York: Harper \& Row. 
This text is taken from Skin, Kin and Clan: The dynamics of social categories in Indigenous Australia, edited by Patrick McConvell, Piers Kelly and Sébastien Lacrampe, published 2018 by ANU Press, The Australian National University, Canberra, Australia.

doi.org/10.22459/SKC.04.2018.05 